\title{
Employee Motivation: A Constant Challenge
}

\author{
Ms. Namrata Shah $^{1 *}$
}

\section{ABSTRACT}

Motivation is a keyinstrument that is often under-utilized by managers in today's workplace. To produce the best results for business in the most efficient and effective fashion, managers use motivation. Motivation is a prime tool to inspire people to work, both individually and in groups in the workplace.

This paper will help at creating a progressive motivational atmosphere for managers to get an effective workforce. Employee motivation has always been a challenge for leaders and managers. Demotivated employees exit the organization if given the opportunity and produce low quality work, these employees are likely to make little or no effort in their jobs, avoid the workplace as much as possible thereby skipping their responsibilities. Contrariwise, employees who feel motivated to work are likely to be determined, resourceful and dynamic, turning out high quality with productivity that they willingly undertake.

Motivation varies in different people. In existing theories, motivation arises, out of needs, values, objectives, intentions, and expectation. Motivating in an effective manner enables negative or difficult tasks to be imparted without creating clashes or ravaging trust. For increase in productivity, efficiency and job satisfaction within the workplace, motivation is de facto crucial.

Keywords: Motivation, Workplace, Managers, Employees

"The term motivation refers to factors that activate, direct, and sustain goal-directed behaviour. Motives are the "whys" of behaviour - the needs or wants that drive behaviour and explain what we do. We don't actually observe a motive; rather, we infer that one exists based on the behaviour we observe." (Nevid, 2013) ${ }^{2}$

People commonly confuse the notion of 'happy' employees with 'motivated' employees. These may be linked, but motivation actually is what causes the act, regardless of the level of happiness. The level of desire employees feel to perform, whether it is getting a glass of water to reduce thirst or reading a book to gain knowledge, is described as motivation.

\footnotetext{
${ }^{1}$ BMS. MBA, MBA through Wales University, United Kingdom *Corresponding Author

${ }^{2}$ http://psychology.about.com/od/mindex/g/motivation-definition.htm (C) 2015 I N Shah; licensee IJIP. This is an Open Access Research distributed under the terms of the Creative Commons Attribution License (http://creativecommons.org/licenses/by/2.0), which permits unrestricted use, distribution, and reproduction in any Medium, provided the original work is properly cited.
} 


\section{Employee Motivation: A Constant Challenge}

It's the need of every manager to cultivate and direct motivation as it is the process that starts, directs, and retains goal-oriented behaviours. Adequately motivated employees are more productive, perform better quality work and feel more invested in their work. It helps employees, their managers and thereby the company, be more successful, when employees feel motivated.

In everyday usage, the term motivation is frequently used to describe the action of a person. The readiness to work at an assured level of effort can said to be motivation. Motivation comes from within us such as thoughts, beliefs, ambitions, and goals. Carefully identifying and addressing these motivating forces and implementing successful motivational programs that increase production and create a positive work environment is the need of the hour for every manager. Motivation has different approaches; therefore, management must find the best fit approach on an individual level for a successful program that would increase productivity and efficiency to reach better results for the organization.

Motivational studies most interests' managers as this may deliver insights into employee behaviour and performance, which in turn helps managers get desired results and improve worker productivity by using the most appropriate motivational techniques.

For any organisation to be successful the employees have to be motivated so as to perform in the right direction which will help the organisation achieve desired results.

\section{Theories of Motivation}

Motivation come from the word 'motive' which means the stimulating factor within individuals like needs, desires, wants. Motivation has been an age old concern and hence there are many theories and approaches that explain the concept. Motivational theories are most relevant to explain behaviour. Motivation is the process of exciting people to act in the desired way to accomplish the goals. To develop an inclination for specific behaviour and desired action, prompt motivation is essential. Below are concepts of motivation most related to the subject at hand:

- Herzberg's two-factor theory ${ }^{3}$

Two-factor theory

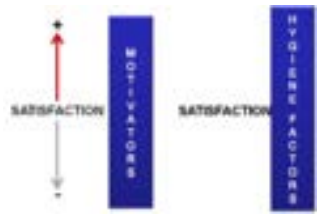

- Frederick Herzberg's two-factor theory determines that at every work place there are factors that cause satisfaction and if these are absent these factors cause no-satisfaction. He also concludes

\footnotetext{
${ }^{3}$ https://www.google.com/search?q=\%E2\%80\%A2\%09Herzberg\%27s+twofactor+theory\&tbm=isch\&tbo=u\&source=univ\&sa=X\&ved=0ahUKEwiuruWOt7HJAhWCWh4KHbyqAt4QsAQIK Q\&biw=1467\&bih=723
} 


\section{Employee Motivation: A Constant Challenge}

that at work place there are hygiene factors, which are not motivators if they are present, but if absent cause dissatisfaction. The factors that motivate people can change over their lifespan. He distinguished between:

- Motivators (e.g. appreciation, responsibility) which give positive satisfaction, and

- Hygiene factors (e.g. status, job security, salary and fringe benefits) that do not motivate if present, but, if absent, result in demotivation.

As per Herzberg's theory, it is established that job satisfaction and dissatisfaction were the products of two unconnected aspects namely motivating factors (satisfiers) and hygiene factors (dissatisfiers). Examples of motivating factors (satisfiers) were: Responsibility, growth, achievement, recognition, work itself, advancement. Examples of hygiene factors (dissatisfiers) were: working conditions, job security, company policy, supervision, interpersonal relations, salary, status, personal life. ${ }^{[2]}$

\section{- Expectancy Theory}

Expectancy theory is another motivation theory which helps us understand employee expectations by connecting effort and reward. This means that an employee will expect to get rewarded if they have worked really hard with extra efforts to achieve a certain objective. In an office scenario, for example, an executive might offer to work a double shift when a manager is short staffed, but would expect praise for doing so.

Appreciation always tends to bring the best out of employees and creates a positive work environment. Managers must learn to apply these courtesies. Managers can do simple things that can have a great impact on organizational morale to motivate associates to "go the extra mile."

Reward and Recognition must be made a part of every organisation and while doing so, managers have to keep several factors of the organisation and its employees. When thinking about rewards and recognition, managers need to think about what works for different people as some factors that work for few employees may not work for the others. Managers also need to keep in account that just because employees are productive doesn't mean they feel valued. The "platinum rule" is that you should do unto others as they would have you do unto them (Kepner and Wysocki, 2002) ${ }^{4}$. A healthier motivational environment would be created with this belief because employees may feel more valued if managers are effectively meeting employee's needs. In the organizational framework the psychological factors stimulating the people's behaviour can be -

${ }^{4}$ Understanding Motivation: An Effective Tool for Managers by Ian Bessell, Brad Dicks, Allen Wysocki, and Karl Kepner -https://edis.ifas.ufl.edu/hr017 
Internal and external motivation processes that an employee experiences result into passionate and persistent behaviour to pursue a certain course of action. Hence, by framing an incentive plan as per employee's needs and wants the organisation can achieve its desired goals. We can say that motivation is a psychological phenomenon which means needs and wants of the individuals have to be tackled thoughtfully. Motivation has a concept that it comes from within; it is only us who can motivate us. We mould our own futures.

However this concept is a philosophy and won't really apply today. All organisations are constantly challenged with a vibrant and changing workforce hence individualized motivation may prove to be a challenge. When employees join any organisation they bring with them with various needs and expectations. Different employees have different beliefs, attitudes, values, backgrounds and thinking. But awareness on workforce diversity, diverse expectation of employees and ways to motivate these employees is a subject of learning for most organizations

\section{Importance of Motivation}

- Motivation helps increase productivity, efficiency and output as employees work sincerely and perform better.

- Employees are energetic and willing to come to work regularly and thus helps in reducing absenteeism

- Motivation also helps control attrition by both financial and non-financial incentive schemes.

- A motivated employee will also help build goodwill in the employment market so as to attract new and right personnel.

- Problems like grievances, indiscipline and labour turnover can be handled by use of motivation.

- Motivation helps develop a sense of belongingness, co-operation and loyalty towards the organisation as proper rapport between employees and their managers is built.

- Organisational goals can be achieved timely by motivation as employees have a feeling of involvement and responsibility. 


\section{Employee Motivation: A Constant Challenge}

\section{Motivation a challenging job}

$>$ Workforce is ever changing and different employees have different needs and wants. Organisations need to understand this diversity and thus think of various ways of motivation for diverse workforce.

> Assumptions need to be made on employees' motives, reason behind employee behaviour and actions, which might not always be right.

$>$ Change of job role, hierarchy and down-sizing in organisations are big motivational challenges

$>$ Employees' need and expectations keep changing during their lifespan and managers need to be aware of such situations.

$>$ Motivation Tree ${ }^{5}$

Rewards + Achievement + Empowerment $=$ GROWTH

Education + Promotion + Responsibility + GROWTH MOTIVATION

\section{Motivation and leadership topples traditional leadership theory}

The key path to success of an organization is motivating employees and staff time to time and acquiringa huge and bright workforce. In short, pampering the employees while still being able to extract one-of-a-kind and outstanding ideas and products from them. The base concept helps to focus more on the results than on the people who deliver those results. Offering the employees distinctive and more than just attractive perksand benefits that just serve to show the very extreme lengths the company aims to go will surely make its employees consistently happy resulting into focused and timely outputs beneficial for the company.

\section{Ways to Motivate}

$>$ Recognition: Employee recognition needs to be personalised. Employee recognition programs can be made more motivational by allowing employees to choose their own rewards.

$>$ Job satisfaction (responsibility, promotion, trainings, empowerment etc): Talking to employees helps improve communication as well as helps in motivation rather than relying on electronic ways to communicate. Employees feel involved with a personal touch that managers' give with personal communication.

Generating and sustaining profits is possible by building a positive motivational environment that attracts, focuses, and keeps talented employees which means employees have to be motivated to come to work regularly, get committed and perform betterconsistently.

\footnotetext{
${ }^{5}$ http://www.actioncoach.com/blog/2015/05/05/increase-motivation-workplace/\#prettyPhoto
} 


\section{Employee Motivation: A Constant Challenge}

Some organisation even Institute a flexible work schedule as per employee preferences, organisations are willing to give employees the choice of flexible work hours that suit their lifestyle or family situation. Flexible work(job sharing, telecommuting and flex-time) can improve employee motivation and retain employees who need a job that is not necessarily a standard9am to 5pm one.

$>$ Rewards: Reward good work. Bonuses and timely pay-outs for increased productivity are motivating to many employees; at least for their basic needs. Pay raises, commissions, performance bonuses, profit sharing, or any number of "extra benefits" like, automobiles, vacations, or other tangible items purchased and used as rewards are other ways of rewarding and motivating employees. Many organisations begin an employeeshareholder program. Organisations permit employees to buy shares in the company at discount prices or allocate certain shares specifically for purchase by of employees.

$>$ Appreciation: Failing to recognise a work well done by employee by a manager, is a way to sabotage employee motivation. This results in loss of direction for the employee. Managers need to be aware of employee performance and give timely appreciation to boost employee morale.

Some employees get motivated by increasing responsibility. These employees will be more motivated to work harder to make the business succeed. Managers must offer employees training opportunities to improve their skills.

$>$ Inspiration: The manager's secret weapon for employee motivation is understanding that many employees crave and do things for recognition what they will not do for money. A simple opportunity to get their name on the wall, receive a trophy at an annual banquet, or see their name in the company newsletter motivated these employees. Few ways of motivation by inspiration are putting up employee and team posters with pictures for a task well achieved, circulating an appreciation email throughout company with employee and team names, giving out awards for attendance records etc. These are ways that are inexpensive yet very effective for employee motivation.

Good leadership always inspires employees. Motivation by a good leader always includes company's mission, purpose and goals. Good leadership helps build market goodwill, it sustains existing people and attracts new people, because people want to be a part of a successful organisation that stands for something, and that provides a meaningful service to the marketplace.

\section{CONCLUSION}

The level of energy, commitment, and creativity that a company's workers bring to their jobs can be termed as employee motivation. Motivational theories either stress on incentives or employee involvement (empowerment). Organisations may choose any method, it is important to have a system in place that builds employee motivation. People are different and so have to be the methods of motivation. Same factors of motivation or combined factors may or may not continue to motivate the same person over their lifespan. Not every person is motivated by the 
same factor, or combination of factors. Offering all five motivation factors- satisfaction, appreciation, recognition, inspiration and rewards ensures that the organization has something to contribute to the level of commitment and job satisfaction of each employee.

\section{REFERENCES}

Boyett, H. Joseph, and Jimmie T. Boyett. (2000). World-class advice on managing and motivating people. Boyett and Associates.

The Manager's Guide to Rewards: What You Need to Know to Get the Best For--And From-Your Employees By Doug Jensen; Tom McMullen; Mel StarkAmerican Management Association, 2007

The Motivation Manifesto, Brendon Burchard(October 28, 2014) by Hay House, Inc

Understanding Motivation: An Effective Tool for Managers by Ian Bessell, Brad Dicks, Allen Wysocki, and Karl Kepner -https://edis.ifas.ufl.edu/hr017

What is motivation by by Kendra Cherry Psychology Expert, http://psychology.about.com/od/mindex/g/motivation-definition.htm 